\title{
Strategi Pengembangan Desa Digital untuk Meningkatkan Produktivitas UMKM
}

\author{
Agus Supriyanto', Kharis Fadlullah Hana ${ }^{2}$ \\ Institut Agama Islam Negeri Kudus ${ }^{12}$ \\ agussupriyanto@iainkudus.ac.id ${ }^{1}$, kharis@iainkudus.ac.id ${ }^{2}$
}

\begin{abstract}
The development of online business has increased very rapidly in 2019. Many people who prefer to buy goods online rather than directly. This is a result of the development of increasingly sophisticated technology with the many features of buying and selling online applications. The presence of online stores that make lifestyle changes in society. Ease and efficiency are the main factors in the people's preference for online transactions. Based on that, the purpose of this study is to analyze the obstacles and constraints of MSMEs to join the online store. After getting the results of the analysis then formulate a development strategy. The research method used is descriptive qualitative research object that is the village of Padurenan. The village was chosen because the MSMEs that have been established are very large for the size of one village of 92 units. The results showed that the padurenan village had made a digital village in 2017. The village was able to support from various parties, but when the members were decreasing and there were only 2 MSME members left. The strategy will be developed also by using the principles of Islamic business ethics. Online sales are based on transparency, honesty and fairness. This encourages the realization of sharia maqasid in doing business in the MSME sector.
\end{abstract}

Keywords: Digital village, online business and MSME

\section{Abstrak}

Perkembangan bisnis online mengalami peningkatan yang sangat pesat pada tahun 2019. Banyak masyarakat yang lebih memilih membeli barang secara online daripada secara langsung. Hal ini diakibatkan oleh perkembangan teknologi yang semakin canggih dengan banyaknya fitur aplikasi jual beli online. Kehadiran toko online itu membuat perubahan gaya hidup dalam masyarakat. Kemudahan dan efisiensi adalah faktor utama preferensi masyarakat dalam bertransaksi secara online. Berdasarkan fenomena tersebut, maka tujuan penelitian ini adalah menganalisis hambatan dan kendala UMKM untuk bergabung dalam toko online. Setelah mendapatkan hasil analisisnya kemudian merumuskan strategi pengembangannya. Metode yang digunakan dalam penelitian ini adalah deskriptif kualitatif. Obyek penelitiannya yaitu desa padurenan. Desa itu dipilih karena UMKM yang telah berdiri sangat banyak untuk ukuran satu desa yaitu sejumlah 92 unit. Hasil penelitian diperoleh bahwa desa padurenan sudah pernah membuat kampung digital di tahun 2017. Kampung itu dapat dukungan dari berbagai pihak, namun saat ini anggotanya semakin menurun dan hanya tersisa 2 anggota UMKM. Strategi yang akan dikembangakan juga dengan menggunakan prinsip etika bisnis islam. Penjualan secara online dilandasi dengan transparansi, kejujuran dan keadilan. Hal ini mendorong terwujudnya maqasid syariah dalam berbisnis pada sektor UMKM.

Kata kunci: Kampung digital, bisnis online dan UMKM 
Agus Supriyanto dan Kharis Fadlullah Hana

\section{PENDAHULUAN}

Perkembangan dunia e-commerce saat ini semakin meningkat, beberapa kemudahan yang disuguhkannya membuat banyak orang menjadi tertarik (Anang Sugara and Rizki Yudhi Dewantara, 2017). E-commerce atau electronic commerce merupakan sebuah mekanisme dalam pengelolaan bisnis secara elektronik, fokusnya adalah pada transaksi bisnis jual beli individu melalui media internet. Teknologi elektronik berbasis internet ini mempertemukan penjual dan pembeli secara langsung dan melakukan pertukaran barang tanpa harus bertatap muka seperti yang ada di pasar tradisional. Hadirnya e-commerce ini mempersingkat waktu untuk saling berhubungan, antara perusahaan dengan entitas bisnis lainnya. Ini karena dengan e-commerce prosesnya lebih cepat, intensif dan murah dibandingkan pada manajemen pasar. Penjualan barang melalui online sudah mulai mengalahkan toko yang ada di pasar. Hal ini dikarenakan oleh beberapa faktor yaitu kemudahan(Alwafi \& Magnadi, 2016), kepercayaan dan kepuasan terhadap sistem (Sugara \& Dewantara, 2017).

Data yang disajikan oleh Badan Pusat Statistik, industri e-commerce di Indonesia dalam waktu 10 tahun terakhir jumlahnya meningkat hingga 17 persen. Jumlah pengguna e-commerce tercatat mencapai 26,7 juta. Pada tahun 2018 peertumbuhan e-commerce di Indonesia mengalami pertumbuhan yang sangat pesat. Kondisi semacam ini diimbangi oleh berkembangnya pengusaha mikro dan menengah. Banyak sekali pelaku usaha mikro yang beralih untuk melakukan transaksi jual beli secara digital. Selain itu juga data tersebut menunjukkan perkembangan e-commerce di Indonesia banyak yang dipengaruhi oleh trend dan pola belanja secara online yang dilakukan oleh para generasi milenial dan generasi Z. Generasi ini sangat suka untu mencari referensi dan membandingkan harga di toko digital. Mereka melihat Fitur dan program promo yang diselenggarakan oleh toko online sebelum mereka mengambil keputusan untuk membeli barang. Apalagi para generasi milenial tidak segan untuk merekomendasikan kepada teman dan orang disekitarnya untuk lebih memilih berbelanja secara online.(Pernama \& Parasari, 2019)

Toko online merupakan bentuk perubahan yang disajikan di generasi 4.0 ini dalam segi inovasi berbelanja (Nusarika \& Purnami, 2015). Fasilitas yang disediakan berbagai toko online disediakan secara gratis oleh pelaku ecommerce, diantaran keuntungan yang didapat ketika jual beli di toko online adalah penjual tidak perlu utuk membuat situs atau website jual beli online sendiri. Situs tersebut memerlukan biaya yang cukup tinggi dan perlu aktivitas yang mendukung agar situs itu dikunjungi oleh banyak orang. Situs e-commerce yang dapat digunakan dengan mudah di Indonesia diantaranya adalah tokopedia.com, bukalapak.com, blibli.com, shopee, zalora, lazada dan sebagainya. Toko online itu dapat diakses dengan mudah dan sangat jarang terjadi gangguan. Masyarakat yang ingin menjadi anggota dan mempunyai toko online tersebut juga sangat mudah. Pendaftar hanya mengisi formulir yang disediakan dengan menyertakan alamat email kemudian membuat 
username dan password selanjutnya verifikasi dan sudah dapat mempunyai toko online sendiri.

Bisnis online banyak mendatangkan keuntungan, namun muncul beberapa masalah yang sering dijumpai pada toko online yang ada di Indonesia. Beberapa permasalahanan tersebut adalah sulitnya membangun kepercayaan pembeli. Menurut Sonja dan Ewald (2003) berbelanja secara online itu memiliki sebuah keunikan tersendiri di bandingkan dengan pola belanja di pasar tradisional. Keunikannya yaitu dari segi ketidakpastian, anonim, minimnya kontrol, dan potensi pengambilan kesempatan oleh para penjual. Konsumen yang membeli melalui toko online dihadapkan pada permasalahan yang pembeli sendiri terkadang tidak dapat mengontrol secara pasti pemenuhan harapannya. Apabila ia membeli pada toko online mereka tidak dapat melihat secara langsung barang yang akan dibelinya apalagi bertemu langsung dengan penjualnya. Berdasarkan hal tersebut, maka harus ada bentuk kepercayaan antara penjual dan pembeli untuk melakukan sebuah transaksi jual beli lewat toko online.

Faktor lainnya yang dapat mempengaruhi keputusan pembelian secara online adalah kemudahan (Budhi, 2016). Penggunaan handphone yang terhubung dengan internet dalam kehidupan sehari-hari seakan sudah menjadi kebutuhan primer saat ini. Apalagi internet itu sangat memudahkan di dalam beraktivitas, terutama dalam bertransaksi jual beli melalui toko online. Kemudahan ini dapat dirasakan oleh pengguna handphone ketika mereka ingin membeli barang secara praktis maka hanya dengan menyambungkannya dengan internet. Berbagai barang yang diinginkan langsung muncul dan konsumen tinggal memilihnya. Barang yang sudah dipilih kemudian dapat dilakukan pembayaran yang juga bisa dilakukan secara online kemudian tinggal menunggu jangka waktu pengiriman. Mereka dapat melakukan transaksi online dimanapun dan kapanpun tanpa tergantung oleh waktu dan tempat seperti pada pasar tradisional.

Pemanfaatan teknologi oleh para konsumen lewat toko online sangat mempengaruhi perkembangan usaha, apabila tidak disikapi dengan baik oleh para pedagang tradisional khususnya adalah UMKM (usaha mikro kecil menengah) maka semakin lama penjualannya akan semakin menuruh karena kalah saing dengan toko online (Suharto, Ardhianto, Ismail, \& Prameswari, 2017). Dengan keadaan yang sudah sedemikian itu, maka perlu adanya trobosan baru bagi UMKM untuk menghadapi semakin ketatnya persaingan usaha lewat toko online saat ini. Hal itu menjadikan perlunya dilakukan pembenahan terhadap UMKM dan menjaga hubungan baik pelanggan dan konsumen untuk jangka panjang (Khairani, Soviyant, \& Aznuriandi, 2018). Pembenahan yang perlu dilakukan adalah dengan memanfaatkan media promosi melalui pembuatan toko online. Manfaat toko online lainnya bagi UMKM adalah dapat meningkatkan produktifitas dan pemasaran UMKM melalui jaringan online yang dapat menghubungkan secara langsung dengan konsumen (Nusarika \& Purnami, 2015). Apalagi pemasaran online pada UMKM yang kecil dan baru dirintis, hal ini cocok karena hemat biaya dengan 
tidak perlu menyediakan gerai untuk memajang produknya. Pemasarannya dapat dikendalikan sendiri tanpa harus merekrut karyawan, waktu kerjanya juga tidak terbatas serta mempunyai jangkauan pasar yang lebih luas. Potensi pasar yang bagus tersebut sayangnya belum ditangkap oleh UMKM di desa padurenan Kudus. Mereka masih mengandalkan pasar tradisional dengan pelanggan tetap yang biasanya melakukan pembelian. Apabila hal itu terus terjadi maka perkembangan UMKM tanpa didukung dengan toko online dalam jangka panjang pasti penjualannya akan berkurang (Rifai \& Luzi Dwi Oktaviana, 2018). Berdasarkan hal itu maka perlu di rancang suatu strategi dalam membangun kampung digital. Kampung/Desa yang berpotensi untuk dikembangkan menjadi kampung digital di Kudus adalah Desa Padurenan. Desa itu merupakan sentra UMKM yang ada di kota Kudus. Dengan adanya penelitian ini diharapkan dapat mengembangkan strategi pengembangan kampung digital di desa padurenan yang dalam kategori desa industri UMKM terbesar di kabupaten Kudus.

\section{KAJIAN TEORI}

\section{Pemasaran Online}

Pemasaran online melalui toko online membantu perusahaan terutama usaha kecil menengah untuk mempromosikan dan memasarkan produk ataupun jasa yang mereka miliki. Pemasaran secara online juga dapat membuka peluang dan pasar baru yang sebelumnya belum ada karena keterbatasan waktu, jarak dan dalam melaksanakan komunikasi. Adanya pemasaran online yang terbuka lebar untuk diakses, maka konsumen berkesempatan dan memiliki akses untuk mengetahui produk yang akan di tawarkan dan tertarik untuk melakukan belanja online.

Belanja online merupakan sebuah kegiatan dalam pembelian produk barang maupun jasa melalui sebuah media yaitu toko online. Kegiatan belanja online biasanya meliputi business to business maupun business to consumers. Berdasarkan penelitian sebelumnya menyatakan bahwa belanja online ini merupakan business to consumers karena pembelian yang telah dilakukan merupakan kegiatan pembelian yang dilakukan langsung oleh konsumen dan tidak untuk dijual lagi produknya. Kegiatan belanja online ini adalah transaksi yang bersifat individu atau ritel dengan pembeli individu, sehingga belanja online ini merupakan sebuah keputusan pembelian yang dilakukan oleh individu secara online. Dalam pemasaran online terdapat 7 tahapan diantaranya adalah Situation Analysis, E-Marketing Strategic Planning, Objectivities, Emarketing Strategy, Implementation Plan, Budget, Evaluation Plan (Tan, Sharma, \& Theng, 2009). Berikut adalah penjelasan dari tujuh tahap tersebut:

\section{a. Situation Analysis}

Tahapan pertama merupakan awal bisnis yang dilakukan dengan melakukan analisis SWOT yaitu kekuatan, kelemahan, peluang serta 
ancaman yang dialami oleh UMKM. Analisis SWOT ini merupakan bagian untuk melakukan identifikasi terhadap berbagai faktor secara sistematis guna merumuskan sebuah strategi untuk diaplikasikan oleh perusahaan. Analisis yang dilakukan berdasarkan logika yang ditemukan oleh seorang analis untuk memaksimalkan kekuatan dan peluang yang bisa dimanfaatkan, selanjutnya baru dilihat dari faktor internal dan eksternal bisnis. Faktor internal disini adalah kekuatan serta kelemahan, sedangkan untuk faktor eksternal yaitu peluang dan ancaman yang datang dari luar perusahaan. Ini menjadi penting untuk diperhatikan karena untuk memetakan posisi dari bisnis tersebut terlatak di koordinat mana, yang pada akhirnya tanti akan bisa diggunakan untuk mengambil sebuah keputusan.

b. E-marketing Strategic Planning

Tahap e-marketing strategic planing ini memiliki tujuh langkahyang bisa digunakan untuk membantu proses evaluasi dan analisis untuk mendapatkan peluang pada suatu pasar. Cara ini dilakukan dengan cara mengidentifikasi apa kebutuhan para pelanggan yang sampai saat ini belum terpenuhi, lalu mengidentifikasi pelanggan yang mana yang akan dituju oleh perusahaan. Langkah selanjutnya adalah menilai keuntungan berkaitan dengan kompetisi yang terjadi. Menilai sumber daya yang ada dalam sebuah perusahaan penting untuk dilakukan, itu berguna untuk memberikan penawaran, menilai tentang kesiapan pasar tentang penggunaan teknologi, yang pada akhirnya akan menentukan peluang yang ada secara kongkret dan untuk menilai peluang dan daya tarik untuk pelanggan. Perumusan strategi perencanaan e-marketing ini meliputi segmentasi, target pasar, diferensiasi produk dan positioning dari bisnis tersebut.

c. Objectives

Tujuan dari e-marketing ini mencakup beberapa aspek yaitu mulai dari tugas, kuantitas serta alokasi waktu. Tugas disini merupakan terkait apa yang hendak dicapai. Kuantitas merupakan berapa banyak yang dihasilkan, sedangkan time frame bisa diartikan kapan waktu pelaksanaannya. Pemasaran online sebagian besar mempunyai sebuah tujuan untuk memenuhi peningkatan pasar, jumlah ulasan yang bagus, upaya untuk meningkatkan pendapatan, efisiensi biaya untuk promosi, mencapai brand image, meningkatkan volume database serta bagaimana mencapai tujuan dari Customer Relationship Management (CRM) itu sendiri. Yang dimaksud CRM disini adalah bagaimana untuk mengingkatkan kepuasan pelanggan, seberapa frekuensi pembelian serta bagaimana customer itu mereferensikan produk kepada pembeli yang lain. Tujuan yang lain adalah untuk memperbaiki pengelolaan suply chain dengan cara meningkatkan koordinasi diantara anggota, menambahkan jumlah mitra serta upaya untuk mengoptimalkan persediaan. 
d. E-marketing Strategy

Strategi pemasaran online yang dimaksud adalah mencakup strategi tentang 4P dan relationship management guna mencapai sebuah tujuan terkait dengan product, price, place dan promotions.

e. Implementation Plan

Tahap ini perusahaan harus memutuskan untuk mencapai tujuan dengan mengimplementasikan strategi yang efektif dan kreatif. Pemasar harus menentukan bauran pemasaran sesuai kriteria 4P, strategi ini kemudian diimplementasikan dengan menyusun rencana untuk pelaksanaannya. UMKM harus memeriksa supaya pemasaran yang telah dilakuukan tepat pelaksanakannya. Mulai dari penyusunan staf, struktur organisasi, departemen, pelayanan customer dan faktor lain yang berasal dari luar perusahaan.

f. Budget

Kunci dari sebuah perencanaan strategis yaitu bagaimana cara mengidentifikasi hasil yang akan dihasilkan dari sebuah investasi. Selama proses penyusunan rencana, pemasar akan bekerja untuk terus memantau pendapatan dan biaya setiap saat supaya bisa memantau hasil yang dicapai. Laporan dari toko online dinilai dari rating berupa berapa bintang yang diperoleh oleh toko online tersebut untuk kemudian digunakan untuk melihat hasil dan catatan untuk mengetahui kepuasan dari pelanggan. Fungsi lain adalah untuk memantau informasi mengenai anggaran yang akan dipertanggungjawabkan, perhitungan revenue forecast perlu dibuat begitu juga dengan intangible benefits atau manfaat tidak berwujud yang diperoleh. Cost savings dan e-marketing cost juga mendapat manfaat dari kondisi ini.

g. Evaluation plan

Perencanaan sebuah promosi online biasanya dilaksanakan kemudian dievaluasi, apakah keberhasilan perencanaan berdasarkan evaluasi yang dilakukan secara berkesinambungan. Jenis evaluasi tergantung tujuan dan rencana yang telah disusun. Dalam menentukan output dari pemasaran UMKM bisa menggunakan sebuah teknik yang biasa disebut balanced scorecard yang berfungsi untuk mengukur kesuksesan dari sebuah penjualan produk yang dimiliki UMKM melalui toko online.

\section{Produktifitas Penjualan UMKM}

Penjualan merupakan sebuah ilmu dan seni untuk mempengaruhi seseorang atau pribadi yang dilakukan oleh penjual, tujuannya adalah untuk mengajak orang lain supaya bersedia untuk membeli produk yang akan ditawarkan. Produktifitas penjualan disini merupakan tingkatan atau jumlah prooduk dan jasa yang bisa dijual sehingga terjadi proses pertukaran produk ataupun jasa. Semakin banyak produk yang terjual 
maka akan dapat dinyatakan semakin produktif usaha yang telah dijalankan tersebut.

Usaha mikro kecil menengah menurut Undang-undang nomor 20 tahun 2008 tentang UMKM yaitu merupakan sebuah usaha produktif yang dimiliki oleh perorangan atau badan usaha perorangan yang sesuai dengan kriteria usaha mikro sebagaimana seperti yang diatur dalam undang-undang adalah sebagai berikut ini:

a. Usaha kecil yang dimaksud disini adalah sebuah usaha ekonomi produktif yang sudah berdiri sendiri dan dikerjakan oleh orang, oleh perorangan atau dikerjakan oleh badan usaha yang bukan anak perusahaan dan bukan cabang dari perusahaan yang telah dimiliki, dikuasai serta sebagai bagian secara langsung atau tidak langsung dari usaha yang memenuhi kriteria usaha menengah atau usaha besar.

b. Usaha menengah diartikan sebagai sebuah usaha ekonomi produktif yang telah berdiri sendiri, dilakukan orang perseorangan ataupun dikerjakan oleh badan usaha yang bukan bagian dari anak perusahaan yang dimiliki, dikuasai,atau menjadi bagian baik langsung maupun tidak langsung dengan Usaha kecil ataupun bagian dari usaha besar dengan jumlah total kekayaan bersih dan jumlah hasil penjualan tahunan seperti yang telah diatur Undang-Undang.

c. Usaha mikro adalah bagian kegiatan usaha untuk dapat memperluas lapangan pekerjaan dan untuk melakukan pelayanan ekonomi kepada masyarakat yang berperan juga untuk proses pemerataan, peningkatan pendapatan, mendorong pertumbuhan ekonomi di suatu daerah, serta ikut andil mewujudkan stabilitas Nasional. Usaha mikro juga merupakan pilar utama ekonomi yang mendapatkan akses dan kesempatan, dukungan, perlindungan dan pengembangan sebagai wujud keperpihakan terhadap kelompok usaha ekonomi rakyat, hal tersebut tidak harus mengabaikan peran dari usaha besar dan BUMN.

Berdasarkan Bab II Pasal 4 dan Pasal 5 Undang-Undang Nomor 20 Tahun 2008 tentang UMKM, adapun prinsip dan upaya pemberdayaan UMKM diantaranya sebagai berikut:

a. Prinsip pemberdayaan UMKM

1) Meningkatkan kemandirian dan kebersamaan supaya jiwa kewirausahaan yang dimiliki oleh UMKM terus tumbuh untuk menghasilkan sebuah karya dengan membuat produk sendiri.

2) Menciptakan keberpihakan kebijakan publik diantaranya supaya transparan, akuntabel serta berkeadilan.

3) Perkembangan usaha yang berbasis potensi akan suatu daerah dan orientasi pasarnya diharapkan sesuai dengan kompetensi yang dimiliki.

4) Meningkatkan daya saing.

5) Penyelenggaraan, pelaksanaan, perencanaan serta pengendalian yang dilakukan secara terpadu. 
b. Tujuan pemberdayaan UMKM

1) Mewujudkan sebuah struktur perekonomian secara Nasional yang seimbang, berkembang dan berkeadilan.

2) Menumbuh kembangkan kemampuan para pelaku UMKM menjadi sebuah usaha yang tangguh dan bisa mandiri dalam pengelolaanya.

3) Meningkatkan peran dan kontribusi dari UMKM dalam pembangunan, pemerataan pendapatan, penciptaan lapangan kerja, pengentasan kemiskinan dan pertumbuhan ekonomi nasional.

Berdasarkan pasal 6 menurut UU No.20 tahun 2008 tentang UMKM, berikut adalah kriteria UMKM:

a. Kriteria usaha mikro

1) Mempunyai kekayaan bersih paling banyak sejumlah Rp. 50.000.000,- (lima puluh juta rupiah) selain tanah dan bangunan yang digunakan untuk memlakukan usaha.

2) Mempunyai hasil penjualan pertahun maksimal sejumlah Rp. 300.000.000,- (tiga ratus juta rupiah).

b. Kriteria usaha kecil

1) Mempunyai kekayaan bersih lebih dari Rp. 50.000.000,- (lima puluh juta rupiah) sampai dengan paling banyak Rp. 500.000.000,- (lima ratus juta rupiah) tidak termasuk bangunan dan tanah tempat usaha

2) Mempunyai hasil penjualan tahunan lebih dari Rp. 300.000.000,(tiga ratus juta rupiah) sampai paling banyak Rp. 2.500.000.000,(dua milyar lima ratus juta rupiah)

c. Kriteria usaha menengah

1) Memiliki kekayaan bersih yang jumlahnya lebih dari Rp. 500.000.000,- (lima ratus juta rupiah) atau maksimal adalah sejumlah Rp. 10.000.000,000,- (sepuluh milyar rupiah), ini belum termasuk tanah dan bangunan yang dipakai untuk menjalankan usaha

2) Hasil penjualan pertahun lebih dari Rp. 2.500.000.000,- (dua milyar lima ratus juta rupiah) sampai maksimal sejumlah $\mathrm{Rp}$. 50.000.000.000,- (lima puluh milyar rupiah).

\section{Bisnis Online}

Perkembangan UMKM di desa padurenan adalah dengan menggunakan bisnis online yaitu dengan jual beli online. Jual beli online diartikan sebagai jual beli barang dan jasa melalui media elektronik pada khususnya adalah melalui media internet. Beberapa penjualan online sekarang lebih memilih penyedia jasa toko online di bandingkan dengan membuat website toko online sendiri. Beberapa media online yang dapat digunakan diantaranya adalah bukalapak.com, tokopedia.com, blibli.com, shopee, lazada dan toko online lainnya. Jual beli melalui media online ini 
adalah sebuah akad jual beli, dilakukan melalui sarana internet untuk melakukan transaksi pertukaran produk baik berupa barang ataupun jasa. Jual beli online ini merupakan sebuah kesepakatan yang dibuat secara bersama-sama dengan menentukan ciri tertentu, yaitu dengan membayarnya terlebih dahulu kemudian barangnya akan dikirimkan kemudian. Jual beli online ini bisa dimaknai juga dengan jual beli dengan menggunakan media internet, proses transaksinya tidak harus bertemu antara penjual dan pembeli secara langsung. Akan tetapi pembayaran dilakukan terlebih dahulu baru dikirimkan produknya melalui jasa pengiriman. Karakteristik transaksi seperti itu dalam islam adalah diperbolehkan, hal itu karena sama dengan akad jual beli salam dan istishna. Sedangkan jual beli secara istishna' merupakan bentuk transaksi dengan sistem pembayaran di segerakan atau ditangguhkan sesuai kesepakatan dan penyerahan barangnya yang di tangguhkan (Prastiwi, 2018).

Terdapat dua jenis komoditas yang diperjual belikan yaitu produk atau jasa baik berupa digital ataupun non digital. Proses jual beli online ini sendiri untuk berbagai macam komoditi non digital. Sedangkan untuk komoditi non digital yaitu seperti ebook, software, script data yang dalam bentuk file dan diserahkan langsung kepada konsumen baik melalui download ataupun email. Komoditi yang di jual belikan pada UMKM adalah komoditi non digital. Barang yang diproduksi UMKM adalah barang jadi seperti seragam, pakaian jadi, gamis dan batik. Adapun bisnis online dalam pandangan ekonomi syariah adalah terbagi dalam bentuk halal atau haram, legal atau ilegal. Bisnis online yang diharamkan adalah transaksi judi, jual beli barang haram seperti minuman keras, makanan haram dan barang ilegal yang tidak jelas merek dan produksinya. Jadi, dasar hukum bisnis online dalam islam pada dasarnya adalah boleh (ibahah) selama proses bisnis tidak terdapat unsur atau elemen yang dilarang. Transaksi jual beli online ini hanya berdasarkan pada deskripsi atau gambaran yang disediakan oleh penjual dan ketika pembeli setuju maka hukumnya adalah sudah dapat dianggap sah. Tentu saja deskripsi produk harus sesuai dengan kondisi produknya, ketika tidak sesuai maka maka pembeli juga mempunyai hak untuk tidak melanjutkan proses pembelian ataupun membatalkannya pembelian produk tersebut.

\section{METODE PENELITIAN}

Metode yang digunakan dalam penelitian ini adalah menggunakan metode kualitatif deskriptif dengan pendekatan konstruktivisme. Peneliti terjun langsung ke lokasi dengan melihat dan merasakan fenomena yang terjadi pada kampung industri kecil menengah selanjutnya melakukan analisis dan mendiskripsikannya. Lokasi penelitian yang dilakukan bertempat di desa Padurenan gebog kudus yang merupakan desa wisata industri terbesar di kabupaten kudus. Peneliti melakukan wawancara 
Agus Supriyanto dan Kharis Fadlullah Hana

terstruktur kepada para responden yang menggunakan promosi lewat online, responden yang tidak menggunakan pemasaran online dan pihak pengurus kampung digital pada desa padurenan.

\section{HASIL DAN PEMBAHASAN}

Berdasarkan data yang diperoleh yaitu di desa padurenan sudah pernah dikembangkan kampung digital untuk memfasilitasi usaha mikro kecil menengah (UMKM) dalam memasarkan produknya sehingga lebih dikenal masyarakat luas. Pangsa pasar yang luas akan membuat tingkat penjualan yang semakin tinggi. Hal ini sudah disadari oleh para pelaku UMKM di padurenan. Mereka sudah membuat website jual beli online yaitu blanja.com yang dikelola oleh KSU padurenan jaya. Situs itu sudah berdiri sejak tahun 2018 dengan jumlah anggotanya mencapai 25 anggota. Situs online tersebut terbentuk berkat bantuan dari telkom yang mempunyai program hibah pembuatan website toko online untuk meningkatkan produktifitas pada UMKM di desa padurenan. Meskipun sudah tersedianya toko online dengan label dan kepemilikan sendiri dari desa padurenan, namun yang terjadi adalah peralihan penjualan dari tradisional ke online sangatlah sulit. Pemilik UMKM desa padurenan sudah nyaman dengan penjualan barang secara tradisional. Mereka sudah memiliki pelanggan tetap yang langsung memesan barang dan dikirimkan ke toko pelanggan. Beberapa pelanggan tetap dari UMKM padurenan adalah pada pemilik toko di pasar kliwon. UMKM padurenan yang bergerak dalam bidang konveksi itu menyuplai pakaian jadi dengan beragam bentuk seperti seragam, gamis, batik, kemeja, baju koko, pakaian anak dan lain sebagainya. Pendapatan merekapun sudah cukup untuk membiayai beberapa karyawannya dan sudah dapat memastikan keberlangsungan usahanya.

Berbagai hal yang dipaparkan oleh para pelaku UMKM lainnya adalah tentang kesulitannya mereka dalam membagi waktu untuk mengurusi pemasaran secara online. Mereka belum memiliki sumber daya manusia yang cukup mumpuni untuk mengatur jalannya usaha melalui toko online (Sugara \& Dewantara, 2017). Hal itulah yang menyebabkan pengembangan kampung digital di desa Padurenan cukup stagnan. Pelaku UMKM sudah terbiasa menjual barangnya ke pasar tradisional. Apabila hal itu dilakukan memanglah tidak terlalu bermasalah untuk perkembangan usahanya dalam jangka waktu pendek. Namun, masalah terjadi ketika era saat ini adalah era internet, diman terjadi pergeseran konsumen yang semula membeli secara tradisional di pasar beralih ke toko online yang praktis dan efisien. Para pembeli tidak perlu datang langsung ke pasar tradisional, mereka hanya cukup menekan handphone yang terkoneksi dengan internet dan memesan barang yang diinginkan. Berdasarkan hal itu maka, diperlukan strategi pengembangan yang tepat pada desa padurenan untuk menghadapi era revolusi industri 4.0 yang saat ini sedang berlangsung. Para pelaku UMKM desa padurenan harus sadar sehingga mereka mampu menangkap peluang yang disediakan oleh toko online. 
Berdasarkan teori tahapan transformasi UMKM menuju ke toko online ada lima langkah tahapan (Malik, 2018) yang telah dimunculkan untuk dijadikan percontohan strategi yang akan dikembangkan pada UMKM desa Padurenan. Strategi pengembangan produktifitas UMKM melalui kampung digital dapat di rumuskan seperti berikut ini(Subba Rao, Metts, \& Mora Monge, 2003):

Gambar 1.1 Strategi pengembangan kampung digital desa padurenan

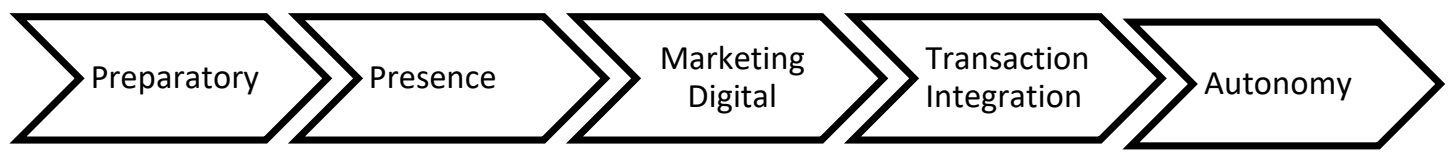

\section{Preparatory}

Preparatory merupakan lanngkah dari pengembangan strategi yang dilakukan pertama kali dalam proses mengembangkan kampung digital. Langkah ini dilakukan dengan cara mempersiapkan para pelaku UMKM untuk melaksanakan pemasaran secara mandiri. Dilakukan oleh pelaku UMKM ataupun dibantu oleh kerabatnya yang melek terhadap teknologi. Karena banyak diantara pelaku UMKM yang masih rendah dalam penguasaan teknologi, banyak diantaranya yang pesimis terlebih dahulu ketika pelaaku UMKM ini tidak menguasai teknologi. Padahal ketika dibiasakan, yang menjadi ketakutan mereka akan mudah untuk ditemukan solusinya.

Teknologi informasi berkembang sangat cepat, perubahan bisnis mengalami pergeseran yang tanpa kita sadari kita sudaah hidup berdampingan dan pangsa pasarnya hampir menyebabkan kekhawatiran dan bahkan ada beberapa perusahaan besar yang harus menutup usahanya. Kehadiran teknologi informasi ini membuat kacau passar yang sudah ada, bahkan bisa dikatakan merusak tatanan bisnis yang sudah berjalan. Pada tahapan persiapan ini, langkah yang dilakukan dimulai dari merubah pola pikir atau midset pelaku UMKM. Usaha yang bisa bertahan adalah usaha yang biisa menyesuaikan dengan perubahan, pemenangnya adalah mereka yang ikut melakukan perubahan itu sendiri. Yang tidak bisa bertahan dengan terpaksa harus mengalami kebangkrutan atau kehilangan pangsa pasar. Menanamkan pola pikir untuk selalu belajar menanamkan pola pikir untuk terus mau belajar perlu ditanamkan sejak awal dalam melakukan pengembangan kampung digital.

Perubahan tidak berhenti pada perubahan mindset saja tetapi dilanjutkan dengan tindak lanjut dengan menyesuaikan pola bisnis yang dilakukan dan pola kerja yang akan dikerjakan. Pelaku UMKM bisa menjalankan bisnisnya selama 24 jam sehari untuk memasarkan produknya, karena sebagus apapun dan sebaik apapun kulaitas produk 
yang dihhasilkan tidak akan ada gunanya kalau tidak diketahui keberadaanya oleh market. Produk yang dipasarkan secara tradisional memiliki keterbatasan yaitu ruang lingkupnya yang sempit, jangkauan wilayah distribusinya hanya pada radius tertentu dan ketika ingin memasarkan prosuk ke wilayah lain dengan cara tradisional memerlukan biaya yang tinggi. Ketika itu dilakukan secara terus menerus akan berdampak pada membengkaknya biaya yang harus dikeluarkan. Sendangkan dengan pemasaran digital proses itu bisa diminimalisir bahkan biaya promosi bisa dikatakan nol atau tidak perlu menganggarkan biaya karena hanya foto produk lalu memposting atau menawarkannya pada sosial media.

Dukungan moril dan material sangat dibutuhkan supaya pelaku usaha ini bisa masuk ke persaingan yang sudah ada, baik dari akademisi, instansi pemerintah ataupun kantor dagang dan industri untuk melakukan pendampingan terhadap pelaku UMKM. Menginngat sangat besar dampak yang akan didapat oleh UMKM ketika bisa masuk pada persaingan bisnis dan peningkatan jumlah transaksi jual beli yang dilakukan secara online. Hambatan-hambatan yang dialami oleh pelaku UMKM ketika bisa dipecahkan dan dicarikan jalan keluarnya, maka harapannya para pelaku UMKM memiliki rasa percaya diri dan mampu memiliki semangat dalam menjalankan usaha.

Tahapan pada kegiatan ini bisa dalam bentuk diskusi dan pendampingan tentang bisnis digital yang dilakukan hanya dengan smartphone dan biaya kuota yang saat ini suudah relatif terjagkau. Komunikasi dan diskusi dengan UMKM harus dilakukan secara intens mengingat perkembangan bisnis digital sangat cepat perubahannya. Begitu media yang digunakan selalu berganti dari periode satu ke periode berikutnya berdasarkan trend yang terjadi di masyarakat. Berbeda dengan pola bisnis sebelumnya yang mana pelaku usaha mudah bertahan dengan dan tanpa merubah poola bisnisnya dalam jagka waktu yang panjang sampai 20 tahun sampai dengan 40 tahun. Bisnis digital berbeda, karena bisa saja tahun ini menjadi trend, tahun yang akan datang sudah ditinggalkan. Hal ini sesuai dengan yang dengan penelitian yang dilakukan sebelumnya oleh (Nusarika \& Purnami, 2015), toko online bagi UMKM dapat meningkatkan produktifitas dan pemasaran.

\section{Presence}

Presence merupakan langkah untuk mengenalkan pelaku UMKM pada pemasaran digital. Kehadiran pelaku usaha untuk meluangkan waktunya dalam mensuukseskan kegiatan ditandai degan peran aktifnya pelaku UMKM dalam menghadiri program pendampingan dan diskusi tentang sejauhmana penguasaan pelaku usaha terkait penggunaan teknologi pemasaran digital. Mulai dari sosial media sampai penguasaan e-commerce yang wilayah jangkauan produknya bisa lebih jauh dan lebih dipercaya oleh market yang ada di Indonesia karena dengan sistemnya 
yang bisa meminimalisir bentuk kecurangan dan penipuan pada proses transaksi jual beli yang dilakukan secara online. Hal tersebut sejalan dengan penelitian (Nusarika \& Purnami, 2015), bahwa toko online merupakan perubahan yang disajikan pada generasi 4.0 dengan keunggulan inovasi berbelanja.

Tahapan ini juga merupakan pendekatan kepada pelaku UMKM dengan diskusi secara rutin dan menyampaikan pemahaman bahwa menggunakan teknologi informasi itu mudah, bisa dilakukan kapan saja dan dimana saja. Keseriusan dalam menghadiri pertemuan dan keaktifan dalam proses diskusi mencari penyelesaian terkait dengan permasalahan yang dihadapi menjadi penting karena ini adalah langkah dari pendampingan untuk mewujudkan kampung digital.

3. Marketing digital

Peningkatan jumlah pengguna internet di Indonesia adalah angin segar bagi pelaku usaha untuk mengenalkan produknya kepada publik. Ini bisa diartikan semakin banyaknya pengguna internet yang ada, maka akan semakin luas juga pagsa pasar yang akan dimasuki untuk pendistribusian produk. Pola belanja masyarakat yang sudah beralih ke transaksi elektronik adalah kesempatan yang baik untuk dimanfaatkan sebagai model bisnis yang baru. Sehingga pada akhirnya tujuan dari pelaku usaha yang menginginkan mendapatkan profit yang tinggi bisa terwujud karena produk langsung bisa didistribusikan sendiri tanpa melalui rantai distribusi dan tanpa harus mengeluarkan biaya sewa properti yang semakin mahal karena terjadi kenaikan tiap tahun. Dengan marketing digital proses pemasaran produk dan pendistribusian produk bisa dilakukan dari rumah dengan cara mengimplementasikan marketing digital.

Tahapan marketing digital ini adalah dengan cara mengajarkan cara membuat e-mail yang nantinya akan digunakan untuk memasarkan produk. Mengajarkan bagaimana menggunakan email mulai dari menulis, membalas sampai memasarkan produk melalui email marketing. Interaksi yang bisa dilakukan dengan cara tatap muka dan berkirim e-mail menjadi solusi untuk melakukan efisiensi proses marketing itu sendiri.

Pemberian alamat dan jenis bisnis di google map dianggap penting, sehingga ketika orang sedang search map, maka akan di suggest apa yang dibutuhkan dan ini juga sebagai media untuk mengenalkan produknya kepada orang yang sedang mengakses google map dan memberitahukan kepada pengguna google map tentang keberadaan bisnis dengan alamat yang bisa dilihat sampai pada foto lokasi yang jelas beserta petunjuk jalan menuju lokasi usaha dari pelaku UMKM.

Sosial media diajarkan untuk memasarkan produk, pembuatan akun sosial media dilakukan mulai dari pembuatan facebook karena penggunanya termasuk paling tinggi di Indonesia dan wilayah 
jangkauannya juga lebih luas karena hampir seluruh warga duia menggunakannya. Di facebook pemasaran dilakukan bisa secara free ataupun berbayar dengan memanfaatkan facebook ads. Tentu saja ada keuntungan dan kekurangan ketika memilih opsi dalam memasarkan produk melalui facebook. Ketika menggunakan yang facebook ads, diajarkan bagaimana membuat iklan yang tepat sesuai demografi dan psikografi dari market yang akan disasar supaya iklan yang dibayarkan itu bisa menjangkau market dan orang yang tepat. Begitu juga penggunaan instagram dan aplikasi sosial media yang lainnya yang bisa digunakan untk membantu memasarkan produk kepada calon customer.

Melakukan pendampingan terhadap pelaku UMKM dalam membuat e-commerce pada toko online yang ada di Indonesia tidak kalah penting untuk diajarkan. Pelaku usaha diajarkan untuk membuat minimal satu user akun pada toko online seperti buka lapak, tokopedia, shopee, olx dan yang lainnya. Faktor penghambat dalam program kegiatan ini adalah kesibukan para pelaku UMKM, banyaknya aktifitas yang dilakukan secara rutin dan menguras tenaga, waktu pelatihan menjadi hal yang mahal. Pengusaan penggunaan digital marketing bagi generasi jaman old terbantu dengan adanya pengganti seperti anak atau cucunya (generasi millenial dan generasi Z) yang sudah terbiasa mengunakan teknologi digital. Penelitian ini mendukung penelitian sebelumnya yang dilakukan oleh (Rifai \& Luzi Dwi Oktaviana, 2018), bahwa UMKM tanpa didukung oleh toko online maka penjualannya akan berkurang.

\section{Transaction Intergration}

Tahapan ini yang adalah tahapan dimana proses transaksi itu akan dilakukan, jadi penting untuk melakukan pendampingan dalam memberikan pemahaman kepada pelaku usaha untuk bisa menggunakan dan bertransaksi dengan menggunakkan transaksi elektronik. Menggunakan mobile banking, menggunakaan e-money dan transaksi digital yang masih jarang sekali menggunakannya atau bahkan banyak diantara yang belum pernah melakukannya sebelumnya. Proses transaksi ini pada dasarnya adalah proses yang sederhana, namun karena ketakutan dari pelaku usaha ini menjadi langkah yang biisa dibilang sulit. Perlu memberikan pemahaman dan meyakinkan bahwa penggunaan transaksi elektronik ini menjadi hal yang aman asalakan menggunaakaan dengan cara yaang benar dan pemahaman penggunaan aplikasii yang benar.

Keterbatasan SDM dalam menggunakan transaksi elektronik perlu menjadi perhatian karena percuma saja produknya banyak yang oorder tetapi waktu transaksi tidak bisa merespon dengan baik. Customer sudah membayar produk, tetapi banyak diantara pelaku UMKM belum merespon dengan cepat sehingga customer kecewa dan memberikan rating rendah pada toko online yang dimiliki oleh UMKM. 
Ketika reputasi di toko online rendah akan berdampak pada tidak adanya trust oelh calon customer yang mengunjungi toko online. Sehingga pada tahapan ini perlu mendapatkan perhatian serius untuk dilakukan pendampingan secara intens sehingga apa hanya diharapkan bisa dilaksanakan sesuai yang telah direncanakan.

\section{Autonomy}

Tahapan selanjutnya adalah autonomy, ini adalah tahapan dimana UMKM melakukan transformasi bisnis menjadi e-UMKM. Harapan dari tahapan ini adalah para pelaku UMKM mampu untuk bersaing dan mampu bersaing dalam memasuki persaingan e-commerce. Banyaknya pelaku usaha sejenis tidak boleh menjadikan pelaku usaha untuk berkecil hati, tingginya angka persaingan yang bahkan diantara pelaku usaha menurunkan harga dan kompetisi pada harga rendah tidak menyurutkan niat pelaku UMKM untuk tetap melakukan transformasi bisnisnya menuju bisnis digital. Peran pemerintah sebagai regulator dan menjadi fasilitator harus terus dilaksanakan untuk membina dan membimbing pelaku usaha agar bisa terus mandiri dalam mengelola usahanya. Tingkat kemandirian pelaku UMKM harus terus terpelihara sehingga pada akhirnya bisa menghasilkan dan menginspirasi para pelaku UMKM untuk terus mampu menyesuaikan dengan kondisi bisnis yang ada.

Peran serta pemerintah dengan KADIN untuk membuat sebuah komunitas dan menggolongkan usaha sejenis, memperluas jaringan sesama pelaku usaha yang ada di daerah menjadi langkah yang perlu diambil, dorongan motivasi harus tetap dilaksanakan secara intens supaya ada kepercayaan diri para pelaku usaha dalam menghadapi persaingan bisnis yang semakin ketat. Dibentuknya komunitas dan dan networking diantara pelaku usaha harapannya akan membawa dampak yang baik bagi pelaku usaha. Sesama pelaku usaha sejenis bisa saling bekerjasama, atau saling support dalam menjalankan bisnis.

Mindset persaingan diantara pelaku usaha sejenis harus terus terwujud, yang pada akhirnya harapan untuk membuat sebuah kerjasama yang saling menguntungkan akan cepat terealisasi. Dengan terbentuknya komunitas diantara pelaku UMKM menjadi bahan pertimbangan bagi pemerintah untuk mengeluarkan sebuah kebijakan terkait kesulitan dan pemecahan masalah yang dialami oleh pelaku usaha dengan program pembinaan yang dilakukan secara terus menerus. Dalam proses pembinaan perlu dibuat struktur organisasi dan koordinator perwilayah pada tiap kecamatan ataupun daerah. Yang pada akhirnya akan menjadi jembatan yang menghubungkan antara pengelola UMKM dengan pejabat pemerintah yang bertugas untuk membina UMKM.

Ide bisnis dan permasalahannya akan mudah ditemukan pemecahan masalahnya ketika ada komunitas, peran dari pemerintah adalah sebagai regulator yang baik dalam mewujudkan apa yang 
diharapkan oleh pelaku usaha. Tahapan ini ada beberapa hal yang dapat diidentifikasi, diantaranya kemampuan dari UMKM dalam menjalankan bisnis digital. Ini merupakan modal untuk mampu berkreasi dan berinovasi menyesuaikan dengan kondisi dan persaingan bisnis yang terjadi.

Hambatan yang berpotensi terjadi adalah jumlah UMKM yang banyak anggotanya, sehingga hal tersebut membuat komunitas UMKM kesulitan untuk menentukan prioritas dari program yang akan dilaksanakan, tarik ulur kepentingan selalu terjadi. Kesadaran diri dari sesama pelaku usaha untuk saling merelakan apabila belum adanya dukungan terhadap kelompok UMKM belum terealisasi menjadi hal yang penting. Adanya komunikasi yang baik antara anggota komunitas UMKM untuk mewujudkan desa digital memungkinkan diantara sesama anggota UMKM untuk saling berinteraksi dan belajar menggali permasalahan dan memecahkan masalah yang dihadapi oleh pelaku UMKM (Subba Rao et al., 2003).

\section{SIMPULAN}

Pengembangan produktifitas UMKM di desa Padurenan melalui sarana kampung digital memang untuk saat ini belum terlalu berkembang walaupun sudah ada website toko online yang telah terbentuk. Hal ini dipengaruhi oleh minat masyarakat yang kurang karena kebiasaan yang sudah sering dilakukan yaitu dengan menjualnya ke pelanggan tetap. Namun, seiring dengan perkembangan jaman, UMKM harus berinovasi untuk menjual produknya ke toko online. Maka diperlukan strategi yang tepat agar UMKM di desa padurenan itu dapat mengembangkan produknya untuk di jual pada toko online. Strategi itu adalah prepatory, presence, portals, transaction intregation dan autonomy. Langkah itu harus dilakukan oleh penggerak UMKM desa padurenan yang dalam hal ini adalah dengan membentuk KSU Padurenan Jaya. Langkah itu juga tidak cukup dengan dukungan KSU Padurenan Jaya, namun kebijakan dari desa dan dukungan dari generasi milenial. Dukungan dari akademisi sangat diperlukan untuk memberikan referensi strategi yang nati akan telah dirumuskan dalam menghadapi perkembangan bisnis yang selalu berubah setiap saat. Harapannya setelah strategi tersebut dapat diimplementassikan. Maka produktifitas UMKM di desa Padurenan akan meningkat. 
Strategi Pengembangan Desa Digital untuk Meningkatkan Produktivitas UMKM

\section{REFERENSI}

Alwafi, F., \& Magnadi, R. H. (2016). Pengaruh Persepsi Keamanan, Kemudahan Bertransaksi, Kepercayaan Terhadap Toko dan Pengalaman Berbelanja Terhadap Minat Beli Secara Online Pada Situs Jual Beli Tokopedia.com. Diponegoro Journal of Management, 5, 1-15.

Budhi, G. S. (2016). Analisis Sistem E-Commerce Pada Perusahaan Jual-Beli Online Lazada Indonesia. Jurnal Electronics, Informatics, and Vocational Education (ELINVO), 1.

Hendrawan, A., Sucahyowati, H., Cahyandi, K., \& Rayendra, A. (2009). Pengaruh Marketing Digital Terhadap Kinerja Penjualan Produk UMKM Asti Gauri di Kecamatan Bantasari Cilacap. Jurnal Administrasi Dan Kesekretarisan, 4(1), 50-61.

Khairani, Z., Soviyant, E., \& Aznuriandi. (2018). Efektivitas Promosi Melalui Instagram Pada UMKM Sektor Makanan dan Minuman di Kota Pekanbaru. Jurnal Benefita, 3(2), 239-247.

Malik. (2018). Transformasi Bisnis UMKM Menjadi E-UMKM.

Nusarika, L. A. K., \& Purnami, N. M. (2015). Pengaruh Persepsi Harga, Kepercayaan, dan Orientasi Belanja Terhadap Niat Beli Secara Online (Studi pada Produk Fashion Online di Kota Denpasar). E-Jurnal Manajemen Unud, 4(8), 2380-2406.

Penelitian, H. (2018). Strategi Pengembangan Usaha Kecil dan Menengah (UKM) Melalui Marketing Online di Dinas Koperasi dan UMKM Kabupaten Banyuwangi. Prosiding Seminar Nasional Hasil Penelitian Dan Pembelajaran, 4(1).

Pernama, G. P. L., \& Parasari, A. A. A. I. (2019). Pengaruh Hedonic Motivation, Social Influence, dan Perceived Enjoyment Terhadap Penggunaan Marketplace Pada UMKM di Bali: Studi Kasus Pada HIPMI Provinsi Bali. Jurnal Ilmiah Manajemen \& Bisnis, 4(1), 90-102.

Prastiwi, I. E. (2018). Pengaruh Persepsi Anggota pada Sharia Compliance, Komitmen Agama dan Atribut Produk Islam Terhadap Customer's Trust yang Berdampak pada Keputusan Menggunakan Jasa Lembaga Keuangan Syariah ( Studi Pada Bmt Amanah Ummah Sukoharjo ). JIEI (Jurnal Ilmiah Ekonomi Islam), 4(01), 28-40.

Rifai, Z., \& Luzi Dwi Oktaviana. (2018). Pelatihan Aplikasi Teknis Online Marketplace Pada Sentra UMKM Banyumas " Pratistha Harsa " Untuk Pemasaran Produk Secara Online. Jurnal Abdimas BSI, 1(3), 593-599.

Subba Rao, S., Metts, G., \& Mora Monge, C. A. (2003). Electronic commerce development in small and medium sized enterprises: A stage model and its implications. Business Process Management Journal, 9(1), 11-32. https://doi.org/10.1108/14637150310461378

Sugara, A., \& Dewantara, R. Y. (2017). Analisis Kepercayaan dan Kepuasan Terhadap Penggunaan Sistem Transaksi Jual Beli Online (Studi Pada Konsumen “ Z"). Jurnal Administrasi Bisnis (JAB), 52(1), 8-15.

Suharto, M., Ardhianto, D. T., Ismail, A. I., \& Prameswari, N. S. (2017). 
Agus Supriyanto dan Kharis Fadlullah Hana

Pelatihan Pengelolaan Website Toko Online Bagi UMKM di Kawasan Pasar Tradisional Klewer Surakarta Sebagai Strategi Menghadapi Masyarakat Ekonomi Asean (MEA). Demandia, 2(2), 229-245.

Susanti, M. (2017). Pemanfaatan E- Commerce Untuk Mendukung UMKM Dalam Pemasaran. Prosiding Seminar Nasional Sisfotek, 3584, 201-208.

Tan, P. J. S., Sharma, R. S., \& Theng, Y. L. (2009). Effective e-commerce strategies for small online retailers. International Journal of Electronic Business, 7(5), 445. https://doi.org/10.1504/ijeb.2009.028151 